\title{
Research Regarding the Behavior of Some Tomato Landraces to Cultivation under Tunnel Conditions
}

\author{
Veronica MAXIM ${ }^{1}$, Dănuț Nicolae MĂNIUȚIU ${ }^{1 *}$, Rodica SIMA ${ }^{1}$, Aurel MAXIM ${ }^{1}$, Ioan Ovidiu MAXIM ${ }^{1}$ \\ ${ }^{1}$ Department of Horticulture, University of Agricultural Sciences and Veterinary Medicine, Cluj- \\ Napoca, Romania \\ *Corresponding to author: dan_maniutiu@yahoo.com
}

BulletinUASVM Horticulture 72(2) / 2015

Print ISSN 1843-5254, Electronic ISSN 1843-5394

DOI:10.15835/buasvmcn-hort:11571

\begin{abstract}
Within the trial was studied the behavior of 3 tomato landraces - SJ 370, SJ 373, AB 343 and a modern cultivar - Saint Pierre to the additional fertilization with two organic fertilizers - Vinasse and OPF. The highest early yields were found with AB $343\left(6.57 \mathrm{~kg} / \mathrm{m}^{2}\right)$ and SJ $370\left(6.53 \mathrm{~kg} / \mathrm{m}^{2}\right)$. The values registered by the variants fertilized with OPF were with 34\% and 33\% higher than those obtained by the standard. SJ 370 registered the highest total yield with a very significant difference compared with the standard. From organoleptic point of view, the most appreciated landrace was SJ 370.
\end{abstract}

Keywords: landraces, Lycopersicon esculentum, tunnel

\section{INTRODUCTION}

The present work is aimed to the improvement and development of tomato crop under tunnel conditions. Thereby it is necessary to reconsider the existent assortment throughout the practical application of the available genetic resources represented by the large number of landraces that are well appreciated for their gastronomic and organoleptic qualities.

At present, tomato landraces are cultivated in open fiel don small surfaces in family gardens. The selection of cultivars with good response to cultivation under tunnel conditions response to the specific techniques of the organic cultivation as the use of organic fertilizers are two concerns of paramount interest at present.

Within the present study three landraces were chosen out of a total of eight. The landraces originated in north-west and center of Transylvania. Their response to cultivation under tunnel conditions and to additional fertilization with two types of organic fertilizers was observed.
The outrunning and extention of harvesting and consumption period were also followed.

Studies concerning the response of landraces to field and protected conditions were realized also by other authors. Thus, Heuwelink (2005) and Jones (2008) reported that tomato hybrids are more productive than landraces, while Cutler (1997), Male (1999) and Coulter (2006) ascertained that some landraces, may show a higher performance than many commercial hybrids, particularly when grown under specific agroclimatic conditions where they evolved in their region of origin.

Multifarious research were realised also regarding the ground and additional fertilization with organic fertilizers.

In general, despite yields may be similar or lower than those observed under conventional practices - the nutritional quality of the organic products is as a whole higher. Gagnon and Berrouard (1993) found an increase of 57-83\% in dry matter content in an experiment testing 13 organic fertilizers. 


\section{MATERIALS AND METHODS}

Between 2013 and 2014 within the Research Station Landwirtschaftskammer NRW, Köln a comparative trial with two factors set in randomised blocks with 3 repeats of 12 plants each, was designed.

The A factor represented the cultivar and had 4 graduations: the landraces SJ 370, SJ 373 AB 343 and the modern commercial cultivar Saint Pierre.

$\mathrm{B}$ factor was represented by the fertilizer applied during the vegetation period and had two graduations: Vinasse and OPF.

Seedlings were transplanted at April $18^{\text {th }}$ and at May $2^{\text {nd }}$ in 2013 and 2014 experiments, respectively.

Usual tomato growing practices for plastic tunnel conditions were done. Observations over the plants growth, flowering and frutification as well as over the fruits morpho-anatomical features, yield and yields dynamics, marketable qualities and organoleptic characteristics were performed.

\section{RESULTS AND DISCUSSION}

The mean number of leaves till the first cluster was comprised between 7.37 and 7.67, the lowest beeing registered by SJ 373 and the highest by $\mathrm{AB}$ 343 (Table 1).

Analysing the growth vigour through the mean number of leaves between clusters and the total number of leaves per plant it followes that in both experimental years the landrace SJ 370 registeres the highest values succeeded by $\mathrm{AB} 343$.

Generaly, the additional fertilization with Vinasse supports plants vegetative growth in comparison with OPF.

SJ 370 and AB 343 showed branched clusters (Table 2).

The landrace SJ 373 and the sort Saint Pierre set simple clusters of 7-9 flowers each.

The mean number of set fruits decreases in the upper clusters more by the landracces and less by the standard Saint Pierre fact that results from the higher load in the lower clusters determined by the higher mean weightof fruits.

Tab. 1 Number of leaves until the first inflorescence

\begin{tabular}{ccccc}
\hline Cultivar & Fertilizer & $\begin{array}{c}\text { Mean number of leaves } \\
\text { until the first inflorescence }\end{array}$ & $\begin{array}{c}\text { Mean number of leaves } \\
\text { between inflorescences }\end{array}$ & $\begin{array}{c}\text { Total number of } \\
\text { leaves per plant }\end{array}$ \\
\hline Saint Pierre & Vinasse & 7.37 & 2.88 & 24.67 \\
\hline Saint Pierre & OPF & 7.42 & 2.93 & 24.94 \\
\hline SJ 370 & Vinasse & 7.67 & 3.32 & 28.38 \\
\hline SJ 370 & OPF & 7.41 & 3.28 & 27.38 \\
\hline SJ 373 & Vinasse & 7.47 & 2.97 & 25.27 \\
\hline SJ 373 & OPF & 7.42 & 2.96 & 27.18 \\
\hline AB 343 & Vinasse & 7.56 & 3.29 & 26.13 \\
\hline AB 343 & OPF & 7.45 & 3.11 & \\
\hline
\end{tabular}

Number of leaves until the first inflorescence

Tab. 2 Plants flowering and frutification

\begin{tabular}{ccccccc}
\hline & \multicolumn{5}{c}{ Fertilization } \\
\cline { 2 - 6 } Cultivar & \multicolumn{3}{c}{ Vinasse } & OPF \\
\cline { 2 - 7 } & $\begin{array}{c}\text { Mean no. of flowers } \\
\text { per inflorescence }\end{array}$ & $\begin{array}{c}\text { Mean } \\
\text { number of } \\
\text { set fruits }\end{array}$ & $\begin{array}{c}\text { Binding } \\
\text { percentage }\end{array}$ & $\begin{array}{c}\text { Mean no. of flowers } \\
\text { per inflorescence }\end{array}$ & $\begin{array}{c}\text { Mean } \\
\text { number of } \\
\text { set fruits }\end{array}$ & Binding percentage \\
\hline St. Pierre & 8.60 & 4.15 & 48.50 & 8.95 & 4.65 & 51.55 \\
\hline SJ 370 & 15.30 & 3.85 & 26.10 & 15.65 & 4.00 & 26.05 \\
\hline SJ 373 & 6.40 & 3.15 & 50.05 & 6.90 & 3.35 & 48.90 \\
\hline AB 343 & 10.45 & 2.00 & 28.55 & 11.55 & 3.40 & 29.80 \\
\hline
\end{tabular}


Supplementary fertilization with OPF stimulates the set of a higher number of flowers per cluster and of set fruits. This effect is more pronounced by the landraces SJ 370 and AB 343 that registered the highest yield per hectare.

\section{Fruits morpho-anatomical features}

In order to characterizethe fruits from morpho-anatomical point of view, observations over the mean weight, shape index, number of seminal chambers and fruits firmness were realized (Table 3).

Per trial, the mean weightof fruits is higher at AB 343 (278.9 g), followed by SJ 370 (241.5 g) and SJ 373 (236.9 gThe sort Saint Pierre had fruits with the mean weight much lower than the landraces (187.2 g). The kind of fertilizer applied during the vegetation period influencedthe mean weight of fruits especially when Vinasse fertilizer was administered.

All the studied cultivars had a shape index below 1 which means that the fruits had a more or less flattened shape. Out of the three landraces, SJ 373 had a shape index close to 1 .

SJ 370 landrace had the most uniform fruits with a round-flattened and slightely shriveled shape. AB 343 has oval-flattened fruits that are more well-marked shriveled.
All the studied landraces have many seminal chambers that gives a higher consistency to the fruits flash. From this point of view, AB 343 and SJ 370 are noticed for having more than 12 seminal chambers. The sort Saint Pierre has the most reduced mean number of seminal chambers (6.0).

The entire studied range had fruits with a better firmness when stored at $5^{0} \mathrm{C}$ and in the variant fertilized with OPF. The most firm fruits were obtained at $A B 343$ in both fertilization variants and stored at $5^{0} \mathrm{C}$. The next place was occupied by Saint Pierre. The other two landraces have a reduced firmness in both storing variants $\left(5^{\circ} \mathrm{C}\right.$ and $20-25^{\circ} \mathrm{C}$ ). To noticed is that SJ 373 fertilized with OPF had fruits with a good firmness in both storaging variants.

\section{Yield and yields dinamics}

During the entire vegetation period the harvest was registered on decades. The early yield was considered till the end of July. The first harvest was on 10.07.2013 respectively on 17.07.2014. It can be observed that in both experimental years and in both fertilization variants $\mathrm{AB} 343$ proves to be the earliest. In dynamics SJ 370 is noticed for the higher level of yield in the first part of the harvesting period that stayes at acceptably levels till the end. Harvesting dynamics show

Tab. 3 Fruits morpho-anatomical features

\begin{tabular}{|c|c|c|c|c|c|c|c|c|c|}
\hline \multirow[b]{2}{*}{ Cultivar } & \multirow{2}{*}{ Fertilizer } & \multirow{2}{*}{$\begin{array}{l}\text { Mean } \\
\text { weight } \\
\text { (g) }\end{array}$} & \multicolumn{2}{|c|}{ Mean size } & \multirow{2}{*}{$\begin{array}{l}\text { Shape } \\
\text { index }\end{array}$} & \multirow{2}{*}{$\begin{array}{c}\text { Crimping } \\
\text { degree }\end{array}$} & \multirow{2}{*}{$\begin{array}{c}\text { Mean } \\
\text { number } \\
\text { of seed } \\
\text { chambers }\end{array}$} & \multicolumn{2}{|c|}{$\begin{array}{c}\text { Mean firmness } \\
\left(\mathrm{kgf} / \mathrm{cm}^{2}\right)\end{array}$} \\
\hline & & & $\mathrm{h}(\mathrm{cm})$ & $\emptyset(\mathrm{cm})$ & & & & $5^{\circ} \mathrm{C}$ & $\begin{array}{c}20- \\
25^{\circ} \mathrm{C}\end{array}$ \\
\hline $\begin{array}{c}\text { Saint } \\
\text { Pierre }\end{array}$ & Vinasse & 187.2 & 58.56 & 72.20 & 0.81 & sleek & 5.9 & 5.3 & 4.7 \\
\hline $\begin{array}{l}\text { Saint } \\
\text { Pierre }\end{array}$ & OPF & 199.2 & 52.96 & 65.43 & 0.81 & sleek & 6.0 & 6.1 & 4.1 \\
\hline SJ 370 & Vinasse & 241.5 & 50.09 & 76.51 & 0.66 & $\begin{array}{c}\text { slightly } \\
\text { shriveled }\end{array}$ & 11.7 & 5.0 & 4.0 \\
\hline SJ 370 & OPF & 216.5 & 48.96 & 72.82 & 0.67 & $\begin{array}{c}\text { slightly } \\
\text { shriveled }\end{array}$ & 11.3 & 5.7 & 3.2 \\
\hline SJ 373 & Vinasse & 236.9 & 55.04 & 67.82 & 0.84 & shriveled & 6.6 & 4.9 & 4.4 \\
\hline SJ 373 & OPF & 221.4 & 53.69 & 64.24 & 0.83 & shriveled & 6.7 & 5.0 & 5.0 \\
\hline AB 343 & Vinasse & 278.9 & 60.74 & 92.12 & 0.66 & shriveled & 14.7 & 6.0 & 4.5 \\
\hline AB 343 & OPF & 259.7 & 55.43 & 80.68 & 0.68 & shriveled & 13.8 & 7.0 & 3.9 \\
\hline
\end{tabular}


by all cultivars a gradual decreas from August to September which is in conformity with the reduced fruit set in the upper clusters.

From dynamics point of view all the landraces reacted better to the fertilization with OPF. With a good harvesting dynamics it can be also remarked AB 343 (Figure 1).

\section{Early yield}

The mean early yield considered till 31.07. represents $34.8 \%$ from the total. This it can be considered a good result for an assortment of middle late tomatoes cultivated under tunnel conditions and organic fertilized.

The highest levels of of early yield were registered by AB $343\left(6.57 \mathrm{~kg} / \mathrm{m}^{2}\right)$ and SJ $370(6.53$ $\mathrm{kg} / \mathrm{m}^{2}$ ) fertilized with OPF. These values were with $34-33 \%$ higher than the standard's (Table 4).

\section{Total yield}

In average on two years the total yield was higher by SJ 370 with a difference of $0.69 \mathrm{~kg} / \mathrm{m}^{2}$ in comparison with AB 343 and of $2.23 \mathrm{~kg}$ compared with the standard Saint Pierre. The registered differences were very significant (Table 5).

In average on the entire trial the additional fertilization with OPF determins a very significant increase of the yield of $2.17 \mathrm{~kg} / \mathrm{m}^{2}$ compared with the fertilization with Vinasse (Table 6).

Analising the combined influence of both factors over the mean level of the yield was found that SJ 370 fertilized with OPF assures the best

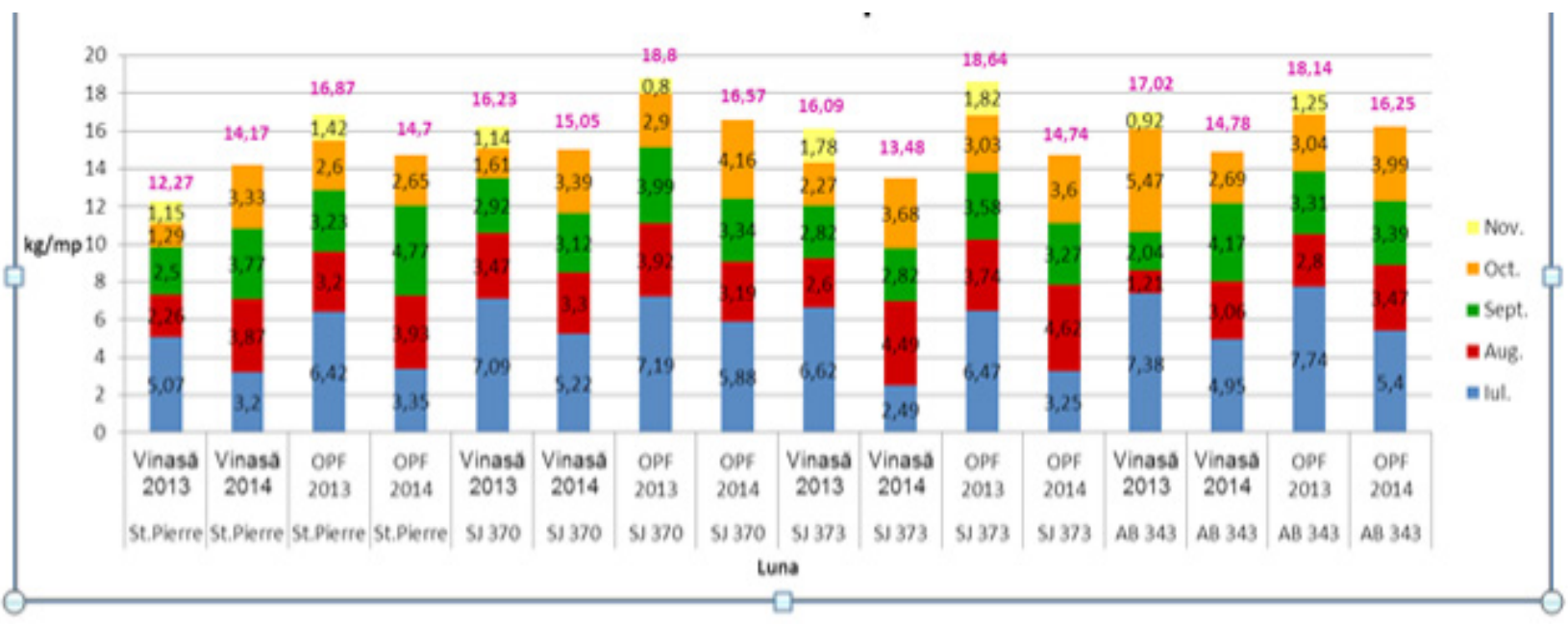

Fig. 1 Harvesting dynamics in 2013 and 2014

Tab. 4 Effect of both, fertilizer and cultivar over the early yield

\begin{tabular}{lcccc}
\hline \multicolumn{1}{c}{ Cultivar } & $\begin{array}{c}\text { Early yield } \\
\left(\mathbf{k g} / \mathbf{m}^{\mathbf{2}} \mathbf{)}\right.\end{array}$ & $\mathbf{\%}$ & Difference $\mathbf{\pm} \mathbf{k g} / \mathbf{m}^{\mathbf{2}}$ & Differences significance \\
\hline St. Pierre - Vinasă - Std. & 4,14 & 100.0 & 0.00 & - \\
\hline St. Pierre - OPF & 4.88 & 118.1 & 0.75 & $* *$ \\
\hline SJ 370 - Vinasse Std. & 6.15 & 100.0 & 0.00 & - \\
\hline SJ 370 - OPF & 6.53 & 106.2 & 0.38 & - \\
\hline SJ 373 - Vinasse Std. & 4.54 & 100.0 & 0.00 & - \\
\hline SJ 373 - OPF & 4.84 & 106.7 & 0.30 & - \\
\hline AB 343 - Vinasse Std. & 6.16 & 100.0 & 0.00 & - \\
\hline AB 343 - OPF & 6.57 & 106.5 & 0.40 & \\
\hline
\end{tabular}

LSD: $5 \%-0.47 ; 1 \%-0.69 ; 0.1 \%-1.03$ 
Table 5 Cultivars effect over the total yield

\begin{tabular}{lcccc}
\hline \multicolumn{1}{c}{ Cultivar } & Total yield $\left(\mathbf{k g} / \mathbf{m}^{\mathbf{2}}\right)$ & $\mathbf{\%}$ & Difference $\mathbf{~} \mathbf{~ k g} / \mathbf{m}^{\mathbf{2}}$ & Differences significance \\
\hline Saint Pierre -Std. & 14.50 & 100.0 & 0.00 & - \\
\hline SJ 370 & 16.73 & 115.4 & 2.23 & $* * *$ \\
\hline SJ 373 & 15.74 & 108.5 & 1.24 & $* * *$ \\
\hline AB 343 & 16.04 & 110.6 & 1.54 & $*$ \\
\hline
\end{tabular}

LSD : $5 \%-0.47 ; 1 \%-0.71 ; 0.1 \%-1.14$

Table 6 Fertilizers effect over the yield

\begin{tabular}{lcccc}
\hline \multicolumn{1}{c}{ Fertilizer } & Total yield $\left(\mathbf{k g} / \mathbf{m}^{2}\right)$ & $\mathbf{\%}$ & Difference $\pm \mathbf{~ k g} / \mathbf{m}^{2}$ & Differences significance \\
\hline Vinasă - Std. & 14.67 & 100.0 & 0.00 & - \\
\hline OPF & 16.84 & 114.8 & 2.17 & $* * *$ \\
\hline LSD $5 \%-0.68 ; 1 \%-0.99 ; 0.1 \% \%-1.48$ & &
\end{tabular}

LSD: $5 \%-0.68 ; 1 \%-0.99 ; 0.1 \%-1.48$

Table 7 Effect of both, fertilizer and cultivar over the total yield

\begin{tabular}{|c|c|c|c|c|}
\hline Cultivar & Total yield $\left(\mathrm{kg} / \mathrm{m}^{2}\right)$ & $\%$ & Diferența/ Difference \pm kg/m² & Differences significance \\
\hline St. Pierre - Vinasse & 13.21 & 100.0 & 0.00 & - \\
\hline St. Pierre - OPF & 15.79 & 119.5 & 2.57 & $* *$ \\
\hline SJ 370 - Vinasse & 15.78 & 100.0 & 0.00 & - \\
\hline SJ $370-\mathrm{OPF}$ & 17.68 & 112.0 & 1.90 & $*$ \\
\hline SJ 373 - Vinasse & 14.79 & 100.0 & 0.00 & - \\
\hline SJ $373-\mathrm{OPF}$ & 16.69 & 112.8 & 1.90 & $*$ \\
\hline AB 343 - Vinasse & 14.89 & 100.0 & 0.00 & - \\
\hline $\mathrm{AB} 343-\mathrm{OPF}$ & 17.19 & 115.4 & 2.30 & $* *$ \\
\hline
\end{tabular}

LSD: $5 \%-1.36 ; 1 \%-1.98 ; 0.1 \%-2.97$

Table 8 Effect of both, cultivar and fertilizer over the total yield

\begin{tabular}{lcccc}
\hline \multicolumn{1}{c}{ Cultivar } & Total yield $\left(\mathbf{k g} / \mathbf{m}^{2}\right)$ & $\mathbf{\%}$ & Difference $\pm \mathbf{~ k g} / \mathbf{m}^{\mathbf{2}}$ & Differences significance \\
\hline St. Pierre - Vinasse & 13.21 & 100.0 & 0.00 & - \\
\hline SJ 370 - Vinasse & 15.78 & 119.4 & 2.57 & $* * *$ \\
\hline SJ 373 - Vinasse & 14.79 & 111.9 & 1.58 & $* *$ \\
\hline AB 343 - Vinasse & 14.89 & 112.7 & 1.68 & - \\
\hline St. Pierre - OPF & 15.79 & 100.0 & 0.00 & $* *$ \\
\hline SJ 370 - OPF & 17.68 & 112.0 & 1.89 & $*$ \\
\hline SJ 373 - OPF & 16.69 & 105.7 & 0.90 & $*$ \\
\hline AB 343 - OPF & 17.19 & 108.9 & 1.40 & \\
\hline
\end{tabular}

LSD: $5 \%-1.07 ; 1 \%-1.57 ; 0.1 \%-2.38$

results $\left(17.68 \mathrm{~kg} / \mathrm{m}^{2}\right)$ followed by $\mathrm{AB} 343$ with the same fertilizer. The diference of $0.4 \mathrm{~kg} / \mathrm{m}^{2}$ between the two fertilization variants is not srtatistically ensured (Table 7).

In general, all the cultivars reacted better to OPF due to it's more balanced mineral content.
Assessing the effect of each fertilizer over the yield, similar results are noticed. Thereby the classification is the same, SJ 370 realising the highest yield in both fertilization variants (Table 8). 
Interpretation of the yields data through the Duncan test confirms the results found through the analise realised with the method of limits difference. Thus SJ 370, AB 343 and SJ 373 fertilized with OPF achieve the highest yields (16.69-17.68 $\mathrm{kg} / \mathrm{m}^{2}$ ) without statistically ensured differences

Compared with the standard fertilized with OPF just SJ 370 realises a statistically ensured increase of yield with a value of $12 \%$.

\section{Yields quality}

The results regarding fruits marketable quality expressed in mean values of two years, marks the superiority of Saint Pierre fertilized with OPF in which case the volume of first quality yield and it's percentage of the total is much more higher than in case of landraces (Table 10).

From fruits point of view it is noticed AB 343 fertilized with OPF which registeres a higher total yield and a lower percentage (77.43\%) of first quality fruits from the total, compared with the standard.

In general, the entire studied assortment had quality indicators with higher values in case of fertilization with OPF.

\section{Organoleptic features}

The organoleptic assesment concerning the taste, flavour and skin thickness marks the value of SJ 370 followed by the standard Saint Pierre (Table 11).

Tab. 9 Combined influence of both factors over the total yield

\begin{tabular}{|c|c|c|}
\hline Cultivar & Total yield $\left(\mathrm{kg} / \mathrm{m}^{2}\right)$ & Classification \\
\hline SJ $370-\mathrm{OPF}$ & 17.68 & $\mathrm{a}$ \\
\hline AB $343-$ OPF & 17.19 & $\mathrm{ab}$ \\
\hline SJ $373-$ OPF & 16.69 & $\mathrm{ab}$ \\
\hline St. Pierre - OPF & 15.79 & $\mathrm{bc}$ \\
\hline SJ 370 - Vinasse & 15.78 & bc \\
\hline AB 343 - Vinasse & 14.89 & $\mathrm{c}$ \\
\hline SJ 373- Vinasse & 14.79 & $\mathrm{c}$ \\
\hline St. Pierre - Vinasse & 13.21 & $\mathrm{~d}$ \\
\hline
\end{tabular}

SD $5 \%=1.42-1.56$

Tab. 10 Yields quality

\begin{tabular}{|c|c|c|c|c|c|}
\hline \multirow[b]{2}{*}{ Cultivar } & \multirow[b]{2}{*}{ Fertilizer } & \multicolumn{4}{|c|}{ Yield $\left(\mathrm{kg} / \mathrm{m}^{2}\right)$} \\
\hline & & Total & $\mathbf{1}^{\text {st }}$ Quality & $2^{\text {nd }}$ Quality & $\begin{array}{l}\text { Percentage of } 1^{\text {st }} \text { quality } \\
\text { fruits from the total }\end{array}$ \\
\hline Saint Pierre & Vinasse & 13.22 & 11.89 & 1.33 & 89.94 \\
\hline Saint Pierre & $\mathrm{OPF}$ & 15.79 & 14.39 & 1.40 & 91.13 \\
\hline SJ 370 & Vinasse & 15.78 & 10.73 & 5.05 & 68.00 \\
\hline SJ 370 & $\mathrm{OPF}$ & 17.68 & 11.76 & 5.92 & 66.51 \\
\hline SJ 373 & Vinasse & 14.79 & 9.75 & 5.04 & 65.92 \\
\hline SJ 373 & OPF & 16.69 & 11.26 & 5.43 & 67.46 \\
\hline AB 343 & Vinasse & 14.89 & 10.72 & 4.17 & 71.99 \\
\hline AB 343 & $\mathrm{OPF}$ & 17.19 & 13.31 & 3.88 & 77.43 \\
\hline
\end{tabular}

Tab. 11 Organoleptic features of tomato fruits

\begin{tabular}{lcccc}
\hline \multicolumn{1}{c}{ Cultivar } & $\begin{array}{c}\text { Taste } \\
(\mathbf{1 - 5} \text { points })\end{array}$ & $\begin{array}{c}\text { Flavour } \\
(\mathbf{1 - 4} \text { points })\end{array}$ & $\begin{array}{c}\text { Peel thickness } \\
(\mathbf{1 - 5} \text { points })\end{array}$ & Total points \\
\hline Saint Pierre & 3.95 & 3.00 & 3.50 & 10.45 \\
\hline SJ 370 & 3.97 & 3.00 & 3.60 & 10.57 \\
\hline SJ 373 & 3.10 & 2.75 & 3.20 & 9.05 \\
\hline AB 343 & 3.43 & 2.80 & 3.95 & 10.00 \\
\hline
\end{tabular}


Good taste qualities has also AB 343.

\section{CONCLUSIONS}

Summarising the results obtained in the three trials the following can be concluded:

- SJ 370 and AB 343 have big, rounded or oval flattened fruits, more or less shriveled, with many seminal chambers being flashy and appreciated for their taste;

- in case of landraces cultivation under tunnel conditions the additional fertilization with complex organic fertilizers (Vinasse and OPF) ensures similar results in both experimental years; the OPF fertilizer has better effects over the yield and marketable quality of tomatoes than Vinasse; these results can be assigned to the more balanced chemical composition of the OPF fertilizer ( $8 \mathrm{~N}: 3 \mathrm{P}_{2} \mathrm{O}_{5}: 3 \mathrm{~K}_{2} \mathrm{O}$ ) compared with Vinasse $\left(4,5 \mathrm{~N}: 6 \mathrm{~K}_{2} \mathrm{O}\right)$;

- the highest yield was obtained by SJ 370 fertilized with $\operatorname{OPF}\left(17,68 \mathrm{~kg} / \mathrm{m}^{2}\right)$ followed by $\mathrm{AB} 343$ with the same fertilizer;

- AB 343 proved to be the earliest landrace realising till the end of July between $42,6-49,4 \%$ from the total yield while $S J 370$ realised till the same date $38-42,8 \%$ from the total; harvesting dynamics is influenced by the binding percentage and fruit set in the upper clusters; the mean number of set fruits per cluster gradually decreases due to the large load in the first clusters being also influenced by the larger mean weight of fruits;

- the morpho-anatomical characteristics of fruits specific to each landrace is not essentialy modified by the kind of additional fertilizer;

- even if the organoleptic assesment through tasting has a relative character it confirms the general opinion that the fruits of tomato landraces have better taste; out of the studied cultivars, SJ 370 and AB 343 were appreciated as having the best taste qualities.

\section{REFERANCES}

1. Coulter L (2006). Gardening with heirloom seeds: Tried and true flowers, fruits and vegetables for a new generation, Univ. of NC Press, Chapel Hill, NC.

2. Cutler KD (1997). From wolf peach to outer space: Tomato history and lore, p. 6-10. In: Cutler, K.D. and J. Marinelli (eds.). Tantalizing tomatoes: smart tips and tasty picks for gardeners everywhere, Brooklyn Botanic Gardens, Brooklyn, N.Y.

3. Gagnon B and Berrouard S. (1993). Effectes of several organic fertilzers on growth of greenhouse tomato transplants, Can. J. Plant Sci., Short Communication.

4. Heuwelink E (2005). Crop production science in horticulture: Tomatoes, CABI, Cambrige, M.A.;

5. Jones, Jr. J.B., 2008, Tomato plant culture: in the field, greenhouse and garden, 2nd ed. CRC Press, Bocca Raton FL. 